Original Research Paper

\title{
Momordica balsamina Fruit Extracts Enhances Selected Aspects of the Insulin Synthesis/Secretion Pathway
}

\author{
${ }^{1 *}$ Ananias Hodi Kgopa, ${ }^{2}$ Leshweni Jerry Shai and ${ }^{1}$ Motetelo Alfred Mogale \\ ${ }^{1}$ Department of Biochemistry, Sefako Makgatho Health Sciences University, \\ PO Box 236, Medunsa, 0204. Pretoria, South Africa \\ ${ }^{2}$ Department of Biomedical Sciences, Faculty of Science, \\ Tshwane University of Technology, Private Bag X680, Pretoria, 0001, South Africa
}

\author{
Article history \\ Received: 20-08-2020 \\ Revised: $12-12-2020$ \\ Accepted: $15-12-2020$ \\ Corresponding Author: \\ Ananias Hodi Kgopa \\ Department of Biochemistry, \\ Sefako Makgatho Health \\ Sciences University, PO Box \\ 236, Medunsa, 0204. Pretoria, \\ South Africa \\ Email: ananias.kgopa@smu.ac.za
}

\begin{abstract}
Previous studies have suggested that crude plant extracts of the anti-diabetic medicinal plant, Momordica balsamina (MB) may exert their anti-diabetic effect through either enhancement of insulin sensitivity or inhibition of intestinal glucose absorption. However, the effects of these $M B$ extracts on insulin synthesis and secretion are not well documented in the literature. Therefore, a main purpose of the current research was to examine in vitro effects of $M B$ crude fruit extracts on selected aspects of the insulin synthesis and secretion pathway. The study results indicated that ethanol, ethyl acetate and hexane $M B$ crude extracts had the significantly enhanced the uptake of glucose by RIN-m5F $\beta$-cells in a manner depending on concentration. Furthermore, these same $M B$ fruit extracts significantly increased the quantities of synthesized and secreted insulin by RIN-m5F $\beta$-cells. In addition, significant upregulation of the pre-proinsulin gene levels by the same $M B$ fruit extracts was detected by the conventional end-point Polymerase Chain Reaction (RT-PCR), whereas a significant upregulation of gene expression levels of the two pancreatic glucose sensors (glucokinase enzyme and Glucose Transporter 2 (GLUT2)) as well as the two insulin gene transcription factors Musculoaponeurotic Fibrosarcoma homolog A (MafA) and Pancreatic Duodenal Homeobox-1 (PDX-1) were detected by means of quantitative reverse transcriptase PCR. In conclusion, the outcomes of this research propose that $M B$ fruit extracts may, in addition to their effects on sensitivity of insulin and inhibition of intestinal glucose absorption, exert their anti-diabetic effects through stimulation of both the insulin synthesis and secretion.
\end{abstract}

Keywords: RIN-m5F Cells, Synthesized and Secreted Insulin, Glucose Uptake, Anti-Diabetic, Momordica balsamina

\section{Introduction}

Type 2 Diabetes Mellitus (T2DM) is a metabolic disorder characterized by sustained hyperglycaemia owing to the incapability of the pancreatic $\beta$-cells to complement for peripheral insulin resistance (Prentki and Nolan, 2006; Cerf, 2013). The global prevalence of diabetes, approximately $90 \%$ of which is T2DM was projected to be $9.3 \%$, which amount to 463 million individuals in 2019 and it is also expected to escalate to $10.2 \%$, which is 578 million individuals by 2030 and to 700 million people (10.9\%) by the end of 2045 (Saeedi et al., 2019). Current anti-diabetic treatments (Nkansah et al., 2018) for T2DM include lifestyle intervention strategies and pharmacological management with oral hypoglycaemic agents like sulphonylureas, biguanides, dipeptidyl peptidase-4 inhibitors and sometimes injections with different insulin analogues either as monotherapy or in combination therapy (Chaudhury et al., 2017). However, these conventional anti-diabetic agents are often associated with undesirable side effects, are expensive and often, do not meet their therapeutic targets (Chaudhury et al., 2017; Davies et al., 2018). In light of the increasing prevalence of T2DM, its long-term consequences in terms of morbidity, mortality and economic costs, as well as the problems associated with 
conventional anti-diabetic agents, there is an urgent need for the discovery and/or development of therapeutic alternatives for diabetes that are safe, efficacious and affordable. For the effective use of these alternative antidiabetic agents, especially in combination therapy, it is imperative that their discovery and development be accompanied by knowledge and understanding of their hypoglycaemic mechanisms of action.

Medicinal plants have been used cost-effectively in traditional folk medical systems of many countries to manage an assortment of human illnesses, including diabetes mellitus (Govindappa, 2015; Salehi et al., 2019). Actually, in numerous regions of the globe, particularly in underprivileged nation state, this has been the solely means of treatment accessible to manage diabetes (Joseph and Jini, 2013). Momordica balsamina Linn, (MB). Cucurbitaceae family of plants, commonly known as African pumpkin or Balsam apple, a therapeutic plant that has been used for decades in folk medication to manage diabetes and associated complications (Thakur et al., 2009). The hypoglycaemic effects of $M B$ crude leaf, fruit and seed extracts have been confirmed in zoological simulations of diabetes (Otimenyin et al., 2008; Bhardwaj et al., 2010). $M B$ plant extracts as other well-documented antidiabetic plant extracts may exert their hypoglycaemic effects through wide range of mechanisms including stimulation of insulin synthesis, enhancement of the secretion of insulin by pancreatic $\beta$-cells, enhancement of the sensitivity of insulin and/or intestinal glucose digestion and absorption inhibition (Govindappa, 2015; Wajid et al., 2019). Whereas $M B$ plant extracts are reported to possess an ability to improve insulin sensitivity in insulin unresponsive tissues (Thakur et al., 2009) and to inhibit the intestinal absorption of glucose (Bhardwaj et al., 2010; Santa Cruz and Sfara, 2018), there are no studies in the literature that have investigated and reported on the effect of $M B$ plant extracts on the insulin synthesis and secretion. Thus, the objective of the present study was to explore the effects of $M B$ crude fruit extracts on selected aspects of the pathways that involve synthesis and secretion of insulin in RIN-m5F $\beta$-cells and this include the uptake of glucose, secretion of insulin stimulated by glucose and the total amount of synthesized insulin in addition to effects on the mRNA levels of designated gene whose yields of protein are involved in production of insulin.

In this study, different concentrations of the crude fruit extracts of Momordica balsamina were prepared and the extracts effect on the uptake of glucose, mRNA levels of the pre-proinsulin gene, pathways in which insulin is synthesized and secreted as well as the determination of MafA, PDX-1, Glucokinase and GLUT2 mRNA levels in RIN-m5F were investigated To the greatest of our knowledge, this study is one of its kind to explore and report on the effect of Momordica balsamina crude fruit extracts which is likely to provide valuable information about the exact mechanisms whereby these plant extracts exert their blood glucose lowering effect. This information can then be used to avoid the undesirable herb-drug interactions when these plant extracts are used alongside conventional synthetic anti-diabetic drugs.

\section{Materials and Methods}

\section{Research Design}

The flow diagram of the research approach in this current study presented in the Fig. 1 and the large indices nomenclature as used in the article is presented in Table 4

\section{Plant Material Collection, Identification and Extraction}

The unripe fruits of $M B$ were collected in MentzSegoreng village, Ga-Mamabolo, Limpopo Province, South Africa (235' $\left.54.3^{\prime \prime S}, \quad 29^{\circ} 46^{\prime} 44.3^{\prime \prime} \mathrm{E}\right)$. The taxonomic distinctiveness of this plant validated in Pretoria by a taxonomist at the South African National Biodiversity Institute (SANBI) and the plant sample representing the verified species of the plant were deposited with the sole identification code PRE099641300 . The collected $M B$ fruits were rinsed with running tap water, sliced into portions and frozen at $-80^{\circ} \mathrm{C}$ awaiting investigations. Upon usage, frosted fruit pieces were freeze-dried and ground into fine powder. Fifty grams of the dried fruit powder extracted consecutively with hundred and fifty milliliters each of water, ethanol, ethyl acetate and hexane following the technique mentioned by (Mogale et al., 2011). Each of the resultant crude extraction was filtered by means of Whatman no. 1 filter paper and the ethanol, ethyl acetate and hexane extract was concentrated under vacuum by means of a rotating Büchi evaporator from Lasec $(\mathrm{SA})$ at $37^{\circ} \mathrm{C}$, while extract from water was prepared by freeze-drying through the Vacutec lyophilizer from Lasec (SA). Each crude extract was dissolved separately in $100 \%$ DMSO to prepare stock solution of $20 \mathrm{mg} / \mathrm{mL}$ concentration.

\section{Culturing of Liver and Pancreatic Cells}

The RPMI-1640 culture media enriched with $0.1 \mathrm{~g} / \mathrm{L}$ streptomycin and 10000 units/mL penicillin $(1 \%(\mathrm{v} / \mathrm{v})$ concoction solution an antibiotic as well as $10 \%(\mathrm{v} / \mathrm{v})$ Foetal Bovine Serum (FBS) was used to maintain the growth of liver cells (H-4-II-E (ATCC ${ }^{\circledR}$ CRL1548 ${ }^{\mathrm{TM}}$ )) at $37^{\circ} \mathrm{C}$ in $5 \% \mathrm{CO}_{2}$ incubator. This same RPMI-1640 media also improved with addition of $1 \mathrm{mM}$ sodium pyruvate, $10 \% \mathrm{FBS}$ and $10 \mathrm{mM}$ HEPES to maintain the pancreatic RIN-m5F beta cells at $37^{\circ} \mathrm{C}$ in a moistened thermosphere of $5 \% \mathrm{CO}_{2}$ incubator. Culture media in these cells were changed three to four times a week and cells were seeded for testing when confluence was at eighty-ninety percent. 


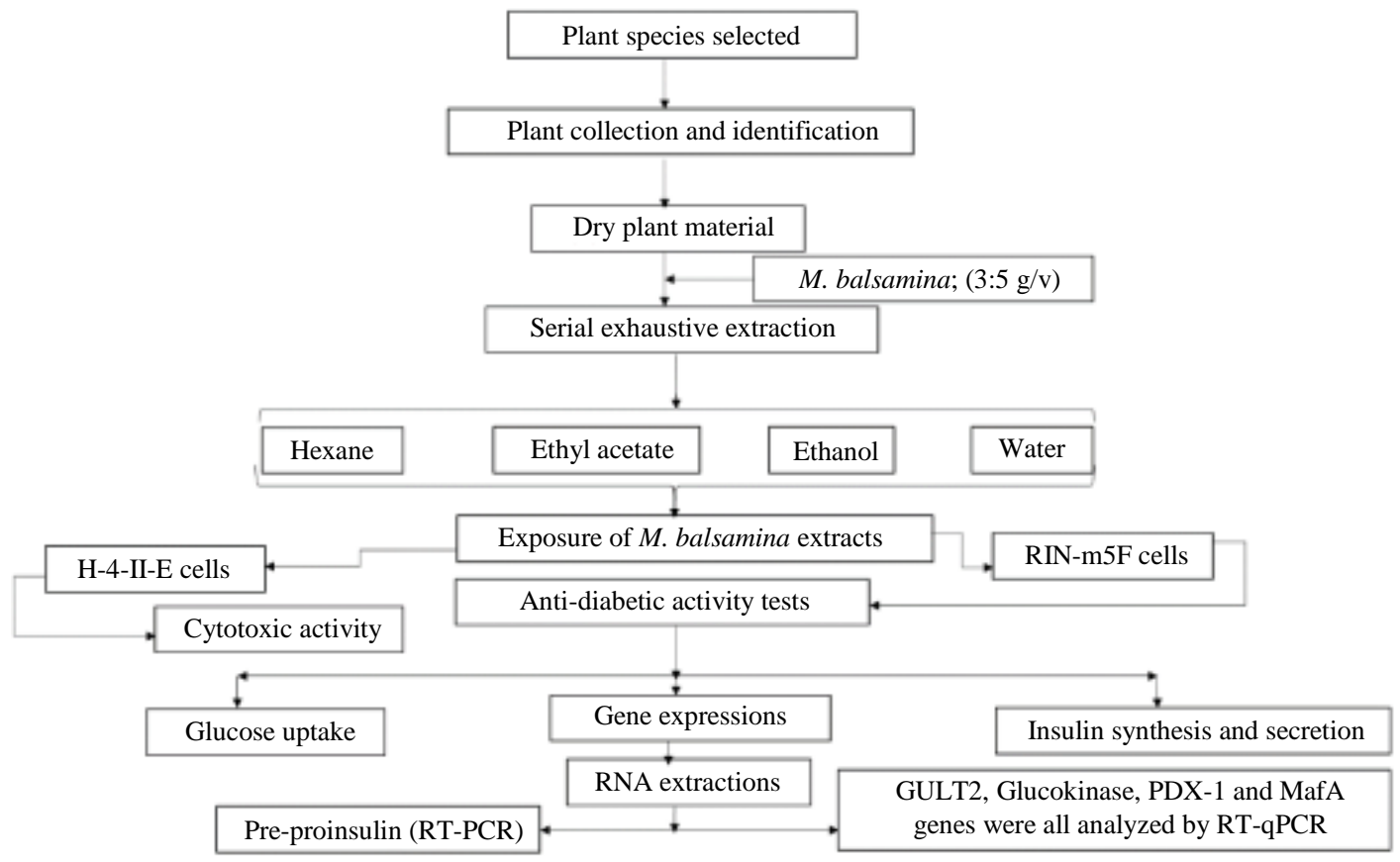

Fig. 1: Flow chart displaying research approach

\section{Cytotoxicity Test}

The effect of $M B$ fruit extracts on liver cell viability was examined by means of the 3-(4,5-dimethylthiazolyl2)-2,5-diphenyltetrazolium bromide (MTT) assay protocol described by (Bahuguna et al., 2017), with modifications. In summary, liver cells cultured at a density of $1 \times 10^{5}$ cells/well were harvested and seeded in 96-well microtiter plates (Lasec, SA) and then grown in an incubator with $5 \% \mathrm{CO}_{2}$ at $37^{\circ} \mathrm{C}$ for $24 \mathrm{~h}$. Cells cultured were then incubated for $72 \mathrm{~h}$ with varied doses $(100 \mu \mathrm{L})$ of extracts of $M B$ fruit ranging between 3.125 and $200 \mu \mathrm{g} / \mathrm{mL}$. Hydrogen peroxide (1\% v/v) as well as DMSO $(1 \% \mathrm{v} / \mathrm{v})$ were positive and vehicle controls, respectively. Subsequently, the medium in the plates were removed and each substituted with $5 \mathrm{mg} / \mathrm{mL}$ MTT solution at a volume not exceeding $200 \mu \mathrm{L}$. The formed formazan crystals in these plates were then dissolved by adding $100 \%$ pre-warmed DMSO to individual plates. The plates were then incubated for $4 \mathrm{~h}$ in the dark, after which, the absorbance were measured at $570 \mathrm{~nm}$ using an ELISA plate reader (ThermoFisher Scientific, SA). The cytotoxic effect of the $M B$ fruit extracts was expressed as percentage of the untreated control using the formula presented here:

$$
\% \text { Cell death }=\frac{\left(A_{\text {treated cells }}-A_{\text {blank }}\right)}{\left(A_{\text {untreated control cells }}-A_{\text {blank }}\right)} \times 100
$$

The LC50 (lowest concentration of plant extract causing $50 \%$ cell death) was calculated from a percentage cell death plot versus of plant extracts concentration (Sagbo et al., 2018).

\section{Stimulation of Glucose Uptake by RIN-m5F Cells}

The uptake of glucose by RIN-m5F cells was examined by means of a revised technique detailed by (Roffey et al., 2007), with amendments. Briefly, cultured RIN-m5F cells maintained previously as reported were seeded at a $2 \times 10^{5}$ cells/well in a 96 -well microtiter plates and incubated at $37^{\circ} \mathrm{C}$ in $5 \% \mathrm{CO}_{2}$ for $72 \mathrm{~h}$. Following attachment post incubation, cells were washed once with RPMI-1640 medium without serum and then incubated for $2 \mathrm{~h}$ at $37^{\circ} \mathrm{C}$ in the same medium $(100 \mu \mathrm{l} /$ well $)$. Afterwards, cells were rinsed twice in $1 \mathrm{X}$ glucose-free Krebs-Ringer Bicarbonate HEPES (KRBH) buffer (4.7 $\mathrm{mM} \mathrm{KCl}, 128 \mathrm{mM} \mathrm{NaCl}, 1.25 \mathrm{mM} \mathrm{CaCl} 2,5 \mathrm{mM}$ $\mathrm{NaHCO}_{3}, 10.5 \mathrm{mM} \mathrm{NaH}_{2} \mathrm{PO}_{4}, 1.25 \mathrm{mM} \mathrm{MgSO} 2,20 \mathrm{mM}$ HEPES, pH 7.4) enriched with $0.1 \%$ Bovine Serum Albumin (BSA) and incubated for $30 \mathrm{~min}$ at $37^{\circ} \mathrm{C}$ in 100 $\mu \mathrm{L} /$ well $1 \mathrm{X}$ glucose-free KRBH buffer. Afterwards, media in the wells was taken out and substituted by $1 \mathrm{X}$ KRBH buffer $(100 \mu \mathrm{l} /$ well $)$ enriched with glucose $(15 \mathrm{mmol} / \mathrm{L})$ and $0.1 \%$ BSA and cells were then incubated in fruit extracts of $M B$ in an increasing concentrations ranging between $1.6 \mu \mathrm{g} / \mathrm{mL}$ and 50 $\mu \mathrm{g} / \mathrm{mL}$. The cell concoctions then incubated at $37^{\circ} \mathrm{C}$ in a $5 \% \mathrm{CO}_{2}$ incubator for $60 \mathrm{~min}$. Subsequently, the quantity of the remaining glucose in the media was confirmed via glucose oxidase-based assay kit (KAT Medical Laboratory, SA) according to the manufactures's procedure. The quantity of the effected intake of glucose 
by four $M B$ fruit extracts was calculated as the difference amongst the preliminary $15 \mathrm{mmol} / \mathrm{L}$ glucose and the remaining glucose in the growth media. All the experiments were performed in triplicate $(n=9)$.

\section{Extracellular and Intracellular Insulin Assays}

The RIN-m5F cells were stimulated by treatment with varying doses of MB fruit extracts for the insulin synthesis and secretions assays following method detailed by (Zhang et al., 2014), with modifications. Subsequently, the sum of intracellular and extracellular insulin quantities was summed to calculate the overall quantity of synthesized insulin. Cultured RIN-m5F cells maintained as previously indicated in the cell culture section were harvested and seeded at a density of $2.5 \times 10^{5}$ cells/well in a 24-well plate in pre-warmed RPMI-1640 media and then incubated at $37^{\circ} \mathrm{C}$ in a humidified atmosphere of $5 \% \mathrm{CO}_{2}$ for $48 \mathrm{~h}$ for attachment. Following attachment, cells were washed in $0.1 \% \mathrm{BSA}$ and then incubated for $20 \mathrm{~min}$ in $5 \% \mathrm{CO}_{2}$ at $37^{\circ} \mathrm{C}$. Additionally, cells were washed two times with $1 \mathrm{X} \mathrm{KRBH}$ buffer free-ofglucose and incubated at $37^{\circ} \mathrm{C}$ in $5 \% \mathrm{CO}_{2}$ incubator for $30 \mathrm{~min}$ with $12.5,25$ and $50 \mu \mathrm{g} / \mathrm{mL} M B$ fruit extracts each containing $15 \mathrm{mmol} / \mathrm{L}$ glucose. Thereafter, plates were shared into two portions, with one-part used for assaying insulin secretions and another part used for assaying quantities of intracellular insulin.

The sum of both the secreted insulin stimulated in the presence of glucose and internal quantities of insulin were measured by means of rat insulin enzymelinked immunosorbent assay (Sigma-Aldrich, SA), following manufacturers procedure. Both the secreted and the internal quantity of insulin was normalized by dividing them with the corresponding protein quantities measured by means of Lowry protein assay kit (ThermoFisher Scientific, South Africa).

\section{RNA Extraction and End-Point Polymerase Chain Reaction}

Effect of $M B$ fruit extracts on mRNA levels of the preproinsulin gene was studied by means of the Reverse Transcriptase-Polymerase Chain Reaction (RT-PCR) following procedure reported by (Kgopa et al., 2020). Briefly, the RIN-m5F cells grown in a RPMI-1640 media enriched with $10 \mathrm{mM}$ HEPES, 10\% (v/v) FBS, $100 \mu \mathrm{M} \beta$ mercaptoethanol and $1 \mathrm{mM}$ sodium pyruvate were seeded in 6-well plates and incubated at $37^{\circ} \mathrm{C}$ in a $5 \% \mathrm{CO}_{2}$ incubator for $48 \mathrm{~h}$. Afterwards, cells were then washed and incubated for $16 \mathrm{~h}$ at $37^{\circ} \mathrm{C}$ in a $5 \% \mathrm{CO}_{2}$ with $\mathrm{MB}$ fruit extracts $(1.25,25$ and $50 \mu \mathrm{g} / \mathrm{mL})$ using the same medium comprising of $15 \mathrm{mmol} / \mathrm{L}$ glucose concentration. Negative control were the non-treated cells while vehicle control were the cells treated with DMSO.

The entire ribonucleic acid was isolated from the RIN-m5F cells treated with $M B$ fruit extracts and non- treated control cells using GeneJet RNA Kit (ThermoFisher Scientific, SA), following manufacturers protocol. The cDNA was transcribed in a reverse direction by means of RevertAid Moloney-Murine Leukemia Virus Reverse Transcriptase kit (ThermoFisher Scientific, SA) with oligo(dT)12 primers and isolated RNA $(0.1 \mu \mathrm{g})$ according to the manufacturer's instructions. The KAPATaq ReadyMix DNA polymerase kit (Lasec, SA) was used to amplify the pre-proinsulin gene and the PCR cycles was performed in My Cycler (Bio-Rad, SA). The forward (5'-TGCCCAGGCTTTTGTCAAAC-3') and reverse (5'-CTCCAGTGCCAAGGTCTGAA-3') primer pairs were used at optimum combinations of $0.4 \mu \mathrm{M}$ for the amplification of this gene. PCR conditions for each 32 cycles were as follows: Denaturation at $95^{\circ} \mathrm{C}$ for $4 \mathrm{~min}$, $95^{\circ} \mathrm{C}$ for $30 \mathrm{sec}, 59^{\circ} \mathrm{C}$ for $30 \mathrm{sec}$ and $72^{\circ} \mathrm{C}$ for $2 \mathrm{~min}$ and to a final extension at $72^{\circ} \mathrm{C}$ for $4 \mathrm{~min}$. Glyceraldehyde-3Phosphate Dehydrogenase (GAPDH) was used as the housekeeping control gene and was co-amplified using the following primer pairs: Forward $\left(5^{\prime}-\right.$ ACTTTGGCATTGTGGAAGG-3') and reverse (5'ACACATTGGGGGTAGGAACA-3'). Agarose gel of $1.25 \%$ was used in this study to separate the products amplified by PCR and the amplicons were then visualized via Chemiluminescence Image System (BioRad, SA). Thereafter, an ImageLab software version 5.2.1 program (Bio-Rad, SA) was performed to quantify the amount of mRNA levels of the pre-proinsulin gene.

\section{Quantitative Polymerase Chain Reaction Analysis}

The effect of $M B$ fruit extracts based on mRNA levels of MafA, PDX-1, Glucokinase and GLUT2 genes was quantified by means of reversetranscriptase-quantitative polymerase chain reaction (RT-qPCR). In brief, cultured RIN-m5F cells reported earlier in the cell culture section were treated with $M B$ fruit extracts (25 and $50 \mu \mathrm{g} / \mathrm{mL})$ concentrations and incubated at $37^{\circ} \mathrm{C}$ in a $5 \% \mathrm{CO}_{2}$ incubator for $16 \mathrm{~h}$. Total RNA isolation and the synthesis of cDNA were performed as described earlier in the RNA extraction section. RT-qPCR was carried out using the $2 \mathrm{X}$ SensifAST SYBR Hi-ROX PCR Mix (Bioline Celtic Diagnostics, SA) following the company's procedure and the genes amplification was achieved by means of the StepOnePlus ${ }^{\mathrm{TM}}$ Real-Time PCR Detection System (AB Applied Biosystems, Bio-Rad, SA), with some modification. Pairs of primer used in this analysis were reported by (Kgopa et al., 2020) and are listed in Table 1. mRNA levels of MafA, PDX-1, Glucokinase and GLUT2 gene were measured based on comparative CT technique and were standardized to the comparative mRNA levels of the GAPDH gene using a StepOnePlus software v2.1 (AB Applied Biosystems, Bio-Rad, SA). 
Table 1: Primers used in gene expression analysis

Primer sequences

\begin{tabular}{|c|c|}
\hline Forward primer & Reverse primer \\
\hline GAPDH 5'-ACCACACAGTCCATGCCATCAC-3' & 5'-TCCACCACCCTGTTGCTGA-3' \\
\hline MafA 5'-AGGCCTTCCGGGGTCAGAG-3' & 5'-TGGAGCTGGCACTTCTCGCT-3' \\
\hline PDX-1 5'-AACCCGAGGAAAACAAGAGG-3' & 5'-GTTCAACATCACTGCCAGCTC-3' \\
\hline Rat glucokinase 5'-TGACAGAGCCAGGATGGAG-3' & 5'-TCTTCACGCTCCACTGCC-3' \\
\hline Rat GLUT2 5'-TGGGTTCCTTCCAGTTCG-3' & 5'-AGGCGTCTGGTGTCGTATG-3' \\
\hline
\end{tabular}

Primers used for the respective genes presented

\section{Data Analysis}

All tests were conducted in three independent experiments $(n=9)$ and data are expressed as mean \pm Standard Error of the Mean (SEM). Student's $t$-test with the assumption of equal variance was used to compare experiments and controls. Data was considered statistically significant when a two-tailed p-value were less than 0.001 and 0.05 . The analysis of data was executed by means of Microsoft 16 Excel software.

\section{Results}

\section{Percentage Extract Yield and $L_{50}$ Cytotoxicity Values}

The percentage extracts yield and the $\mathrm{LC}_{50}$ values of the different $M B$ crude fruit extracts obtained by means of the MTT assay are tabulated in Table 2.

As shown in Table 2, the maximum percentage of extract yield was attained with water extraction and the extract with the least percentage yield was achieved with hexane extraction. The $M B$ crude ethanol fruit extract was the most toxic of the four extract (lowest $\mathrm{LC}_{50}$ ) while the ethyl acetate fruit extract was the least toxic. The $\mathrm{LC}_{50}$ values in Table 2 were used to inform the $M B$ crude fruit extracts concentration used in all the performed experiments in the current study (i.e., in all experiments carried out in the study, each extract was used at concentration below its $\mathrm{LC}_{50}$ in order to limit cell death due to extract toxicity).

\section{Uptake of Glucose by RIN-m5F Cells}

Effect of increasing concentrations of $M B$ crude fruit extracts on consumption of glucose by RIN-m5F cells were explored as described in the methodology section and the result are shown in Fig. 2.

As shown in Fig. 2, the $M B$ fruit hexane and ethyl acetate extracts showed a significant enhancement in uptake of glucose by RIN-m5F cells that were treated compared with non-treated RIN-m5F cells in a manner that depends on extract dose from the $3.1 \mu \mathrm{g} / \mathrm{mL}$ concentration up to the $25 \mu \mathrm{g} / \mathrm{mL}$ concentration $(\mathrm{p}<0.05$ ). However, in both extracts, the effect of the extract seemed to drop unexpectedly as the extract concentration increased beyond 25 to $50 \mu \mathrm{g} / \mathrm{mL}$. $M B$ fruit water extract at $1.6,3.1$ and $50 \mu \mathrm{g} / \mathrm{mL}$ also demonstrated a significant enhancement of consumption of glucose by RIN-m5F cells when evaluated against RIN-m5F cells that were not treated $(p<0.05)$. However, in this case, the effect was not dose-dependent. In contrast, the $M B$ fruit ethanol extract at all investigated concentrations in the current study nonsignificantly inhibited the consumption of glucose when compared with non-treated RIN-m5F cells.

\section{Effects of Extracts on Synthesis and Secretion of Insulin}

Effect of $M B$ crude fruit extracts on the glucosestimulated insulin secretions, intracellular amounts of insulin and the total quantity of synthesized insulin by RIN-m5F cells are presented in Fig. 3.

With exception of the water extract, a significant increase in intracellular insulin content in all other concentrations of $M B$ fruit extracts tested in this study was demonstrated in RIN-m5F cells once compared with both the non-treated RIN-m5F cells and the glibenclamide $(0.1 \mu \mathrm{M})$ control $(\mathrm{p}<0.05)$ (Fig. 3A). Similarly, with the exemption of the water extract, a substantial increase in secretion of insulin stimulated by glucose in tested concentrations and overall quantity of synthesized insulin by RIN-m5F cells of all other $M B$ fruit extracts was detected in comparison with nontreated RIN-m5F control cells $(\mathrm{p}<0.05)$ (Fig. 3B and 3C, respectively). However, only $M B$ fruit hexane and water extracts at $50 \mu \mathrm{g} / \mathrm{mL}$ significantly enhanced secretion of insulin stimulated by glucose and increased the overall quantity of synthesized insulin by RIN-m5F cells when comapred with the control drug glibenclamide $(0.1 \mu \mathrm{M}$,) $(\mathrm{p}<0.05)$ (Fig. 3B and 3C, respectively).

\section{Effects of Extracts on Pre-Proinsulin mRNA Levels}

Effect of $M B$ fruit extracts at 25,50 and $100 \mu \mathrm{g} / \mathrm{mL}$ concentrations were examined by means of RT-PCR as reported in the methodology section. The pre-proinsulin mRNA level profile in the RIN-m5F cells treated with $M B$ fruit extracts in comparison with the solvent treated control cells is presented in Fig. 4.

$M B$ crude fruit hexane and ethanol extracts significantly increased mRNA levels of the preproinsulin gene in a dose-dependent manner in RIN-m5F 
cells that were treated when compared with the mRNA levels of the very similar genetic material in non-treated cells $(\mathrm{p}<0.001) . M B$ crude fruit ethyl acetate extract also significantly increased mRNA levels of the preproinsulin gene in RIN-m5F cells that were treated comparing it with mRNA levels of the very similar RNA component in non-treated cells $(\mathrm{p}<0.001)$. However, in this case, the effect of the extract was not dosedependent. In addition, $M B$ crude fruit extract of water at 25 and $50 \mu \mathrm{g} / \mathrm{mL}$ concentrations showed a significant increase in mRNA levels of the gene in RIN-m5F cells treated with extracts compared with non-treated control cells $(\mathrm{p}<0.001)$. In contrast, the water extract of $M B$ fruit at $12.5 \mu \mathrm{g} / \mathrm{mL}$ unexpectedly significantly decreased the mRNA levels of this gene in RIN-m5F cells that were treated compared to the mRNA levels of the very similar gene in non-treated cells $(\mathrm{p}<0.001)$.

\section{Effects of Extracts on MafA, PDX-1, Glucokinase and GLUT2 mRNA Levels}

Effect of $M B$ crude fruit extracts on the PDX-1, MafA glucokinase and GLUT2 mRNA levels in folds are graphically presented in Fig. 5 and in percentage expressions are presented in Table 3. $M B$ fruit ethanol, hexane and ethyl acetate extracts at $25 \mu \mathrm{g} / \mathrm{mL}$ significantly enhanced the increase in mRNA levels of GLUT2 gene 1.6-fold, 2.0-fold and 1.2-fold, respectively in RIN-m5F cells that were treated when compared with the mRNA levels of the very similar gene in non-treated RIN-m5F cells ( $\mathrm{p}<0.05)$ (Fig. 5A). In contrast, $M B$ fruit ethanol, ethyl acetate and hexane extracts, all at 50 $\mu \mathrm{g} / \mathrm{mL}$ concentration, as well as the $M B$ fruit water extract at both 25 and $50 \mu \mathrm{g} / \mathrm{mL}$ concentrations, significantly decreased mRNA levels of the GLUT2 gene 3-fold, 3-fold, 1.86-fold, 2.3-fold and 1.3-fold, respectively, in $\mathrm{RIN}-\mathrm{m} 5 \mathrm{~F}$ cells that were treated when compared with the mRNA level of the very similar gene in non-treated RIN-m5F cells $(\mathrm{p}<0.05)$ (Fig. 5A). $M B$ fruit ethanol, ethyl acetate and hexane extracts, all at $50 \mu \mathrm{g} / \mathrm{mL}$ concentration significantly improved mRNA levels of the glucokinase gene 646-fold, 662fold and 997-fold respectively in RIN-m5F cells that were treated comparing it with mRNA levels of the similar gene in non-treated RIN-m5F control cells $(\mathrm{p}<0.05)$ (Fig. 5B). As presented in Fig. 5C, $M B$ fruit hexane extract, $M B$ fruit ethyl acetate extract, $M B$ fruit ethanol extract and $M B$ fruit water extract, all at $25 \mu \mathrm{g} / \mathrm{mL}$ but not at $50 \mu \mathrm{g} / \mathrm{mL}$ significantly upregulated the expression of PDX-1 gene 9.9-fold, 7.3, 6.2-fold and 5.7-fold respectively in RIN-m5F cells that were treated when compared with nontreated RIN-m5F cells $(\mathrm{p}<0.05)$. Similarly, $M B$ fruit hexane extract, $M B$ fruit ethyl acetate extract, $M B$ fruit ethanol extract and $M B$ fruit water extract at $25 \mu \mathrm{g} / \mathrm{mL}$ significantly enhanced the increase in mRNA levels of MafA gene 17.5-fold, 9-fold, 12-fold and 9-fold respectively in RIN-m5F cells that were treated when compared with mRNA levels of the similar gene in non-treated RIN-m5F cells $(\mathrm{p}<0.05)$ (Fig. 5D). These same $M B$ fruit extracts, at $50 \mu \mathrm{g} / \mathrm{mL}$, significantly increased mRNA levels of the MafA gene 3.5-fold, 2.5fold, 13.2-fold and 3.1-fold respectively compared with the mRNA levels of the similar gene in non-treated RIN-m5F control cells ( $\mathrm{p}<0.05)$ (Fig. 5D).

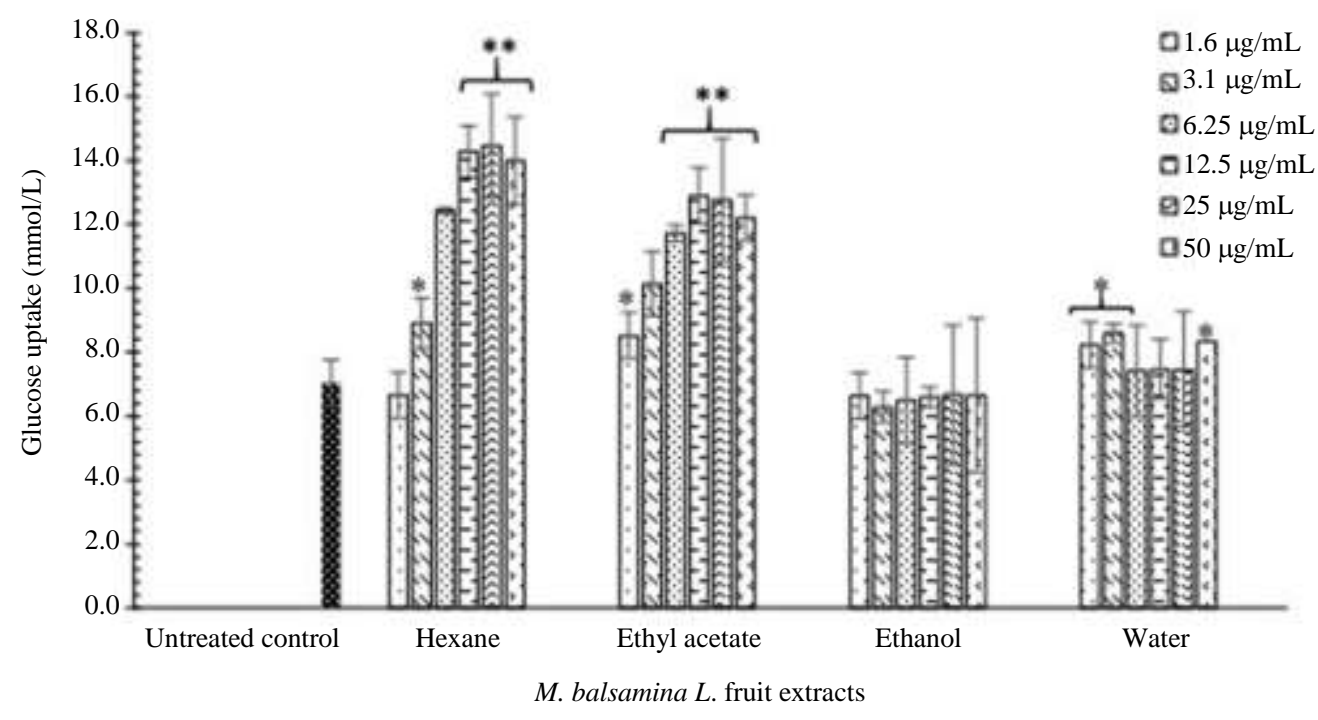

Fig. 2: Effect of $M B$ fruit extracts on the consumption of glucose by RIN-m5F $\beta$-cells grown in glucose concentration (15 mmol/l) for $60 \mathrm{~min}$. Data are mean consumption of glucose \pm SEM of three independent experiments $(n=9)$. * indicate statistical significance at $\mathrm{p}<0.05$ compared with non-treated control cells and $* *$ indicates statistical significance at $\mathrm{p}<0.001$ compared with non-treated control cells 


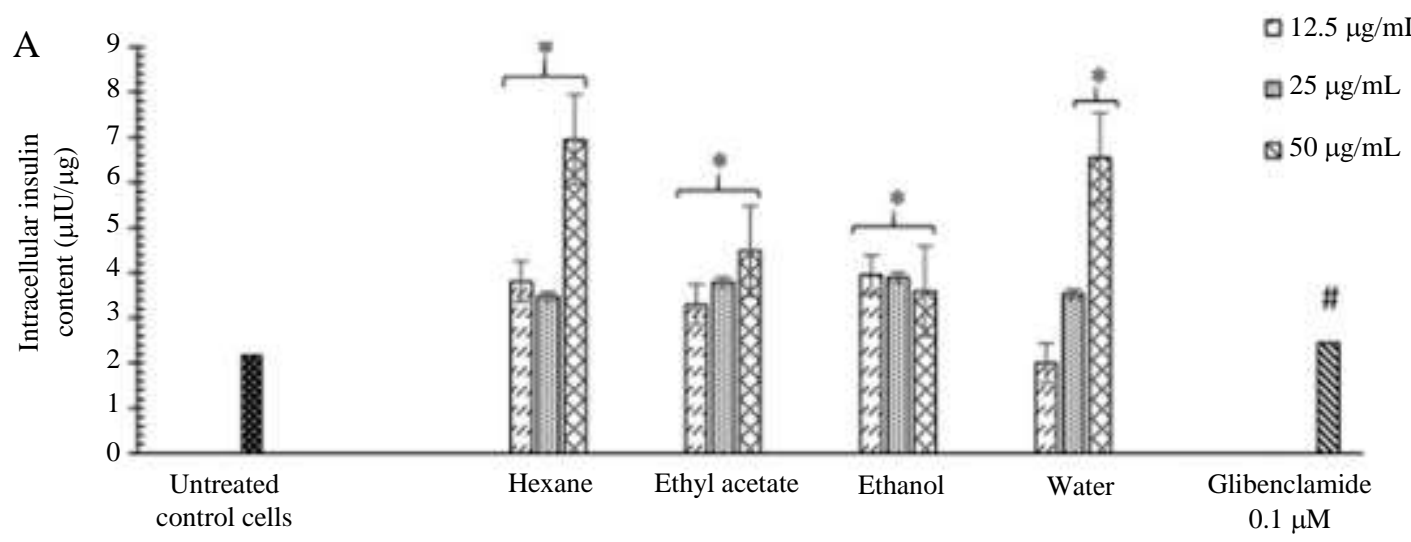

M. balsamina L. fruit extracts
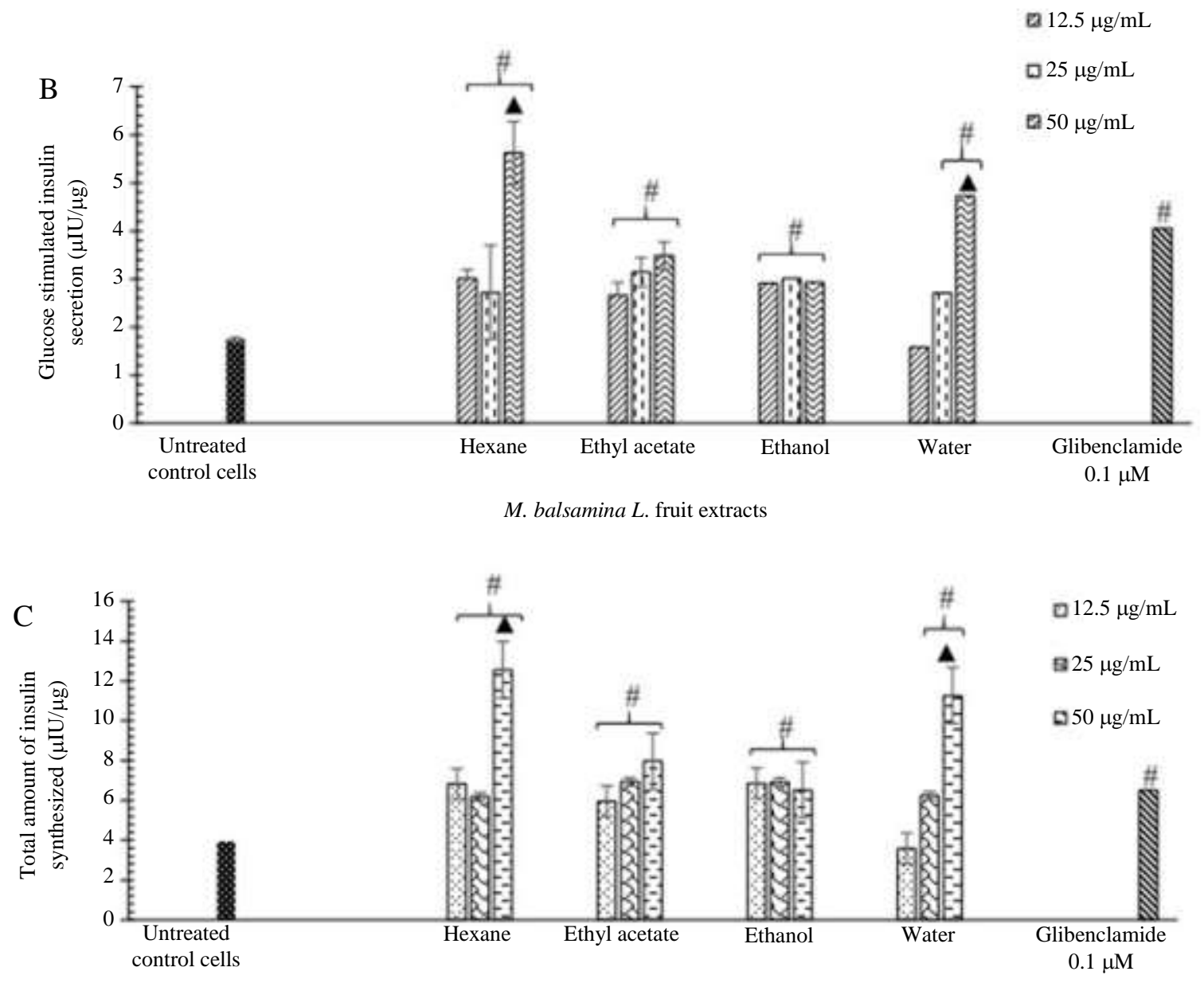

M. balsamina $L$. fruit extracts

Fig. 3: Effect of $M B$ fruit extracts on (A) intracellular insulin amount, (B) glucose-stimulated insulin secretion and (C) synthesis of insulin by RIN-m5F $\beta$-cells. Data are mean of amounts of insulin \pm standard error of the mean of triplicate experiments $(n=9)$. * indicates statistical significance compared with both non-treated control cells and glibenclamide treated cells $(\mathrm{p}<0.05){ }^{\#}$ designates statistical significance when compared with non-treated control cells $(\mathrm{p}<0.05)$ and $\boldsymbol{\wedge}$ indicate statistical significance at $\mathrm{p}<0.05$ when compared with $0.1 \mu \mathrm{M}$ glibenclamide 
A
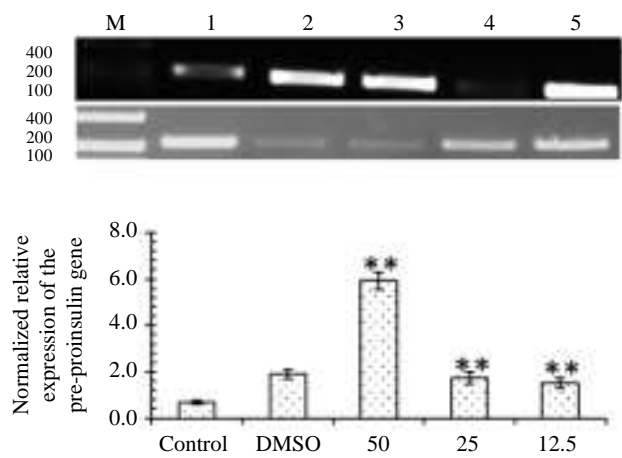

M. balsamina $L$. fruit hexane extract $(\mu \mathrm{g} / \mathrm{mL})$

$\mathrm{C}$
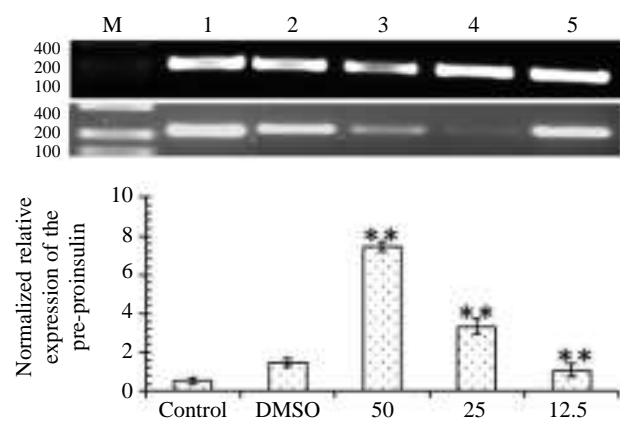

M. balsamina $L$. fruit hexane extract $(\mu \mathrm{g} / \mathrm{mL})$
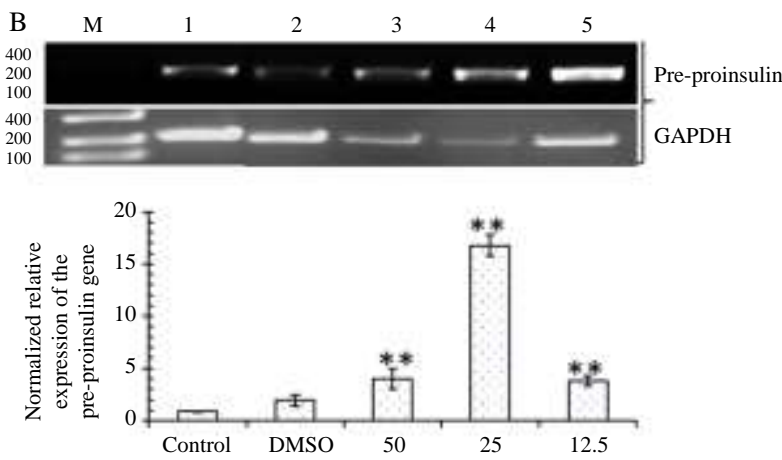

M. balsamina $L$. fruit ethyl acetate extract $(\mu \mathrm{g} / \mathrm{mL})$
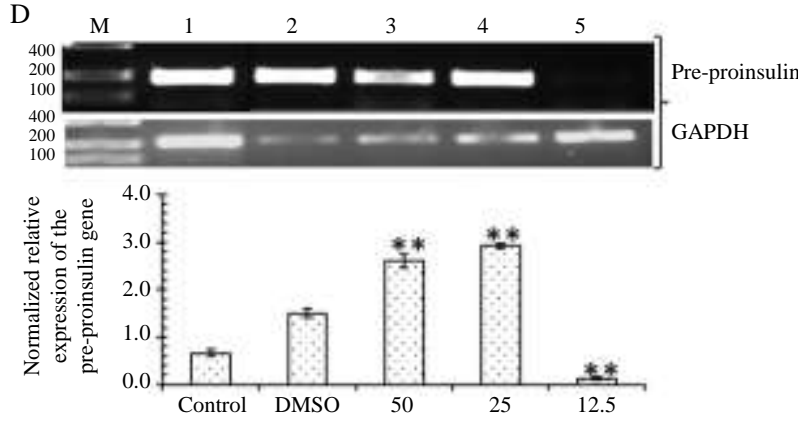

M. balsamina $L$. fruit hexane extract $(\mu \mathrm{g} / \mathrm{mL})$

Fig. 4: Effect of $M B$ fruit extracts on mRNA levels of the pre-proinsulin gene. (A) hexane, (B) ethyl acetate, (C) ethanol and (D) water extract. Data expressed as the -fold change in gene mRNA levels normalized to the GAPDH housekeeping gene. ** indicates statistical significance at $\mathrm{p}<0.001$ when compared with the DMSO control. Lanes: (M) DNA marker, (1) nontreated RIN-m5F control, (2) DMSO and (3-5) Pre-proinsulin gene
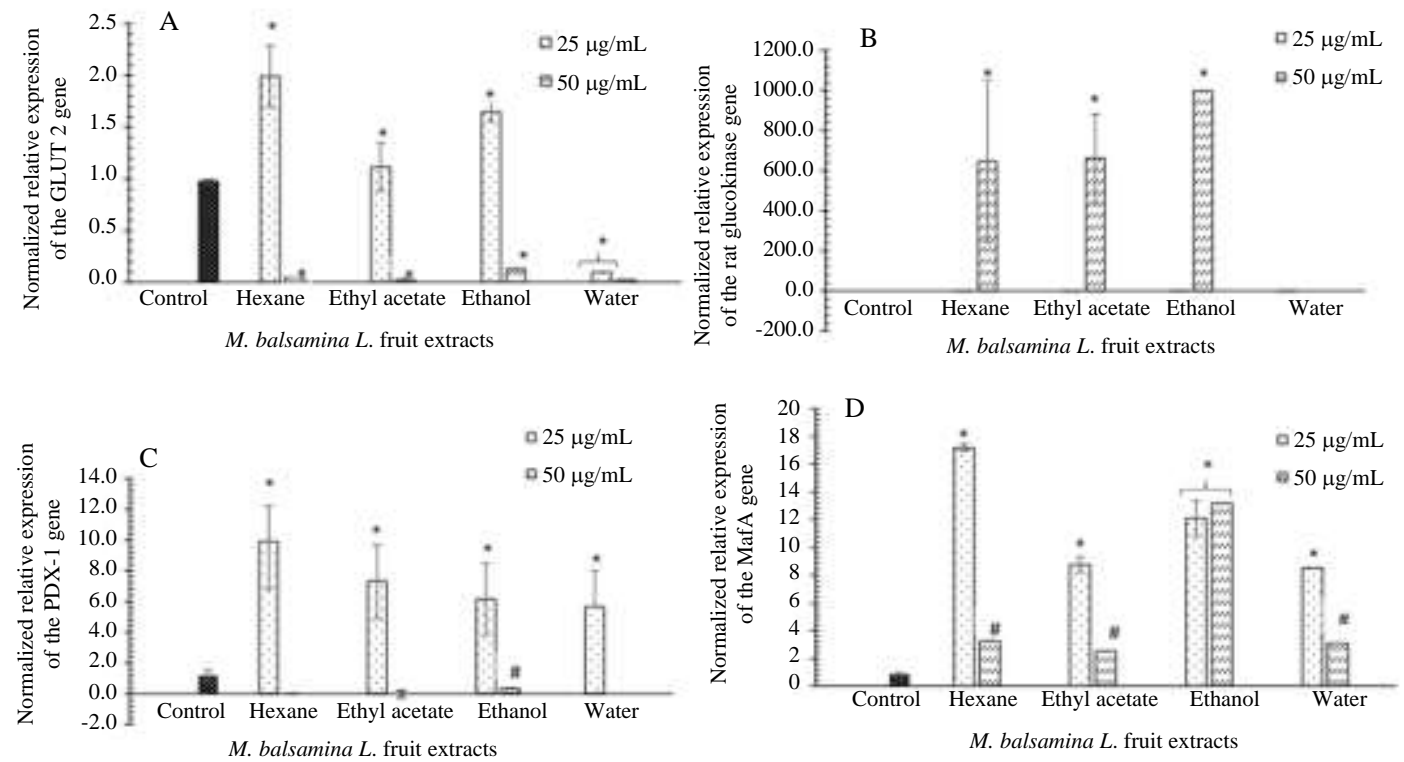

Fig. 5: Effects of $M B$ fruit extracts on the relative expression of (A) GLUT2, (B) glucokinase (C) PDX-1 and (D) MafA mRNAs in RIN-m5F pancreatic beta cells. Data are expressed as the relative fold change in mRNA expression normalized to the GAPDH housekeeping reference gene. * $(25 \mu \mathrm{g} / \mathrm{mL})$ and ${ }^{\#}(50 \mu \mathrm{g} / \mathrm{mL})$ indicates statistical significance at $\mathrm{p}<0.05$ when compared with the untreated RIN-m5F pancreatic beta control cells, respectively 
Table 2: Cytotoxic effects of M. balsamina fruit extracts by H-4-II-E cells

\begin{tabular}{lll}
\hline Extract & Yield $(\%)$ & $\mathrm{LC} 50(\mu \mathrm{g} / \mathrm{mL})$ \\
\hline Hexane & 1.12 & $61.4 \pm 5.02$ \\
Ethyl acetate & 1.26 & $255.2 \pm 0.01$ \\
Ethanol & 1.24 & $49.8 \pm 11.2$ \\
Water & 7.86 & $240 \pm 13.0$ \\
\hline
\end{tabular}

$\mathrm{LC}_{50}=$ Dose of extracts inhibiting cell growth by $50 \%$ presented as means \pm SEM $(n=9)$

Table 3: Percentage gene expression by RT-qPCR

\begin{tabular}{|c|c|c|c|c|c|c|c|c|}
\hline \multirow[b]{2}{*}{ Extract } & \multicolumn{2}{|c|}{$\%$ GLUT2 $(\mu \mathrm{g} / \mathrm{mL})$} & \multicolumn{2}{|c|}{$\%$ Glucokinase $(\mu \mathrm{g} / \mathrm{mL})$} & \multicolumn{2}{|c|}{$\%$ PDX-1 $(\mu \mathrm{g} / \mathrm{mL})$} & \multicolumn{2}{|c|}{$\% \operatorname{MafA}(\mu \mathrm{g} / \mathrm{mL})$} \\
\hline & 25 & 50 & 25 & 50 & 25 & 50 & 25 & 50 \\
\hline Hexane & 50.8 & $<0.0$ & 14.8 & 99.9 & 88.0 & n.d & 95.0 & 73.6 \\
\hline Ethyl acetate & 12.0 & $<0.0$ & 45.6 & 99.9 & 83.8 & n.d & 90.2 & 66.0 \\
\hline Ethanol & 40.6 & $<0.0$ & 37.8 & 99.9 & 80.7 & $<0.0$ & 92.9 & 93.5 \\
\hline Water & $<0.0$ & $<0.0$ & $<0.0$ & n.d & 79.0 & n.d & 89.9 & 72.2 \\
\hline
\end{tabular}

Note: $<0.0 \%$ indicate mRNA level below control levels; n.d indicate genes not detected

Table 4: Large indices nomenclature as used in the article

\begin{tabular}{ll}
\hline Index name & Description \\
\hline GLUT2 & Glucose transporter 2 \\
PDX-1 & Pancreatic duodenal homeobox-1 \\
MafA & Musculoaponeurotic fibrosarcoma homolog A \\
NeuroD1 & B-2/Neurogenic differentiation 1 \\
RIN)-m5F & Rat insulinoma pancreatic beta cells \\
GAPDH & Glyceraldehyde-3-phosphate dehydrogenase \\
T2DM & Type 2 diabetes mellitus \\
MB & Momordica balsamina \\
SEM & Standard error of the mean \\
ELISA & Enzyme-linked immunosorbent assay \\
GSIS & Glucose-stimulated insulin secretion \\
SANBI & South African National Biodiversity Institute \\
MTT & 3-(4,5-dimethylthiazolyl-2)-2,5-diphenyltetrazolium bromide \\
LC50 & Lethal concentration at 50\% \\
KRBH & Krebs-Ringer-Bicarbonate HEPES \\
HEPES & 2-[4-(2-hydroxyethyl)piperazin-1-yl]-ethanesulfonic acid \\
RT-PCR & Transcriptase-polymerase chain reaction \\
RT-qPCR & Reverse transcriptase-quantitative polymerase chain reaction \\
BSA & Bovine serum albumin \\
RPMI-1640 & Roswell Park Memorial Institute, \\
FBS & Fetal bovine serum \\
DMSO & Dimethyl sulfoxide \\
PBS & Phosphate buffered saline \\
cDNA & complementary DNA \\
\hline &
\end{tabular}

\section{Discussion}

The present study investigated the effects of crude fruit extracts of the anti-diabetic medicinal plant, Momordica balsamina, on selected aspects of the insulin synthesis and secretion pathway. In this study, dried $M B$ fruit powder as subjected to a successive extraction with increasing polarity of solvents (hexane, ethyl acetate, ethanol and water) to obtain and examine the effects of phytochemicals of different polarity (non-polar, moderate polar and polar) on the study parameters. Also, in order to limit the toxicity of the plant extracts on RINm5F $\beta$-cells, all extracts used in this study were used at their sub-toxic concentrations (i.e., at concentrations much lower than their corresponding $\mathrm{LC}_{50}$ values) when tested in liver cells.

The glucose entry into $\beta$-cells is essential in both the control of the synthesis and secretion of insulin (Fu et al., 2013; Komatsu et al., 2013; Ren et al., 2007). Hence, the current study investigated among other things, the effect of the different $M B$ fruit extracts on the uptake of glucose by RIN-m5F $\beta$-cells. The results obtained revealed that both the relatively non-polar $M B$ fruits extracts (hexane and ethyl acetate extracts) have the capacity to enhance the uptake of glucose by RIN-m5F $\beta$-cells in a manner that depends on extract dose. This 
capacity could most probably be attributed to the presence of non-polar Cucurbitane-type triterpenoids or their saponins, which are also known to enhance glucose uptake by insulin sensitive tissues (Kaushik et al., 2017) and are reported to be more abundant in $M B$ plant extracts (Thakur et al., 2009). A search of literature revealed that there are no similar previous studies that have investigated and reported on the effects of crude plant extracts on the uptake of glucose by the RIN-m5F cells that do not depend on insulin. Hence, the outcomes of our glucose uptake experiments using RIN-m5F beta cells cannot be compared with results of other studies.

Glucose entry into pancreatic cells is non-insulin dependent, rather, it is controlled by two notable pancreatic beta cell sensors, namely the GLUT2 transporter and the glucokinase (Thorens, 2015). Thus, in order to determine whether the observed enhancement of uptake of glucose by RIN-m5F cells is associated with the upregulation of expressions of either glucokinase, GLUT2 or both genes, the effect of the different $M B$ crude fruit extracts on the mRNA levels of glucokinase and GLUT2 genes were also explored in the current study. The results obtained suggest that both the $M B$ fruit extracts of hexane and ethyl acetate enhanced the uptake of glucose by RIN-m5F cells in a manner that depend on concentration, have the capacity to upregulate the expressions of both GLUT2 and glucokinase at least at the mRNA level. However, in this study, the upregulation of GLUT2 mRNA levels was observed only at $25 \mu \mathrm{g} / \mathrm{mL}$ and not at $50 \mu \mathrm{g} / \mathrm{mL}$ concentration. On the other hand, the upregulation of glucokinase mRNA levels was observed only at $50 \mu \mathrm{g} / \mathrm{mL}$ concentration. The observation that a crude plant extract may have a biological effect at a lower concentration than at a higher concentration have been stated in previous researches (Karthikeyan et al., 2010; Sowemimo et al., 2015; Zandi et al., 2016), however, no suitable explanation has been brought forward to account for this observation. Interestingly, it was also detected in this aspect of the study that the crude $M B$ fruit ethanol extract which did not enhance the uptake of glucose in concentration dependent manner by RIN-m5F cells, significantly upregulated the expression of both glucokinase and GLUT2 genes. Taken together, the results of the uptake and the GLUT2, glucokinase experiments suggest that both the hexane and ethyl acetate $M B$ fruit crude extracts may improve the uptake of glucose by RIN-m5F cells through upregulation of the glucokinase and GLUT2 glucose sensors.

Some medicinal plant extracts reported to exert their glucose-lowering effect through the glucose stimulated insulin synthesis and/or insulin secretion (Ajabnoor, 1990; Mukesh and Namita, 2013; Govindappa, 2015; Noor et al., 2017). Based on these reports, the current study has also investigated the effect of $M B$ fruit extracts on the total quantities of the synthesized and secreted insulin by glucose stimulated RIN-m5F cells. The results obtained from this study suggest that $M B$ fruit hexane, ethyl acetate and ethanol has the ability to stimulate both insulin synthesis and secretion by RIN-m5F cells and hence, the hypoglycaemic mechanism of action for these crude extracts may in part, resemble that of the crude extracts of Biophytum sensitivum (Mukesh and Namita, 2013) and crude extracts of Aloe sp (Ajabnoor, 1990; Noor et al., 2017). In addition, the finding that some crude fruit extracts of $M B$ significantly stimulated GSIS in comparison with the standard insulin secretagoque drug, glibenclamide imply that these extracts may have phytochemicals, most probably saponins that are reported to be more abundant in extracts of the related plant species, Momordica charantia (Keller et al., 2011).

Insulin synthesis is controlled at both the transcriptional and translational level (Fu et al., 2013; Ren et al., 2007; Vanderford et al., 2007). At the transcriptional level, insulin synthesis is regulated by the binding of specific trans-activators including the MafA, B-2/Neurogenic Differentiation 1 (NeuroD1) and the Pancreatic and Duodenal homeobox-1 (PDX-1) to the cis-acting sequences within the 5 ' flanking region of the insulin gene (Fu et al., 2013; Ren et al., 2007). High blood glucose levels within the pancreatic beta cells induce the mRNA levels of the MafA and PDX-1 genes which in turn, stimulate the pre-proinsulin gene levels (Ren et al., 2007; Vanderford et al., 2007). Thus, in addition to the effects of $M B$ fruit extracts on the uptake of glucose and expressions of the two pancreatic glucose sensors, the current study investigated the influence of $M B$ fruit extracts on the pre-proinsulin expressions levels, PDX-1 and MafA mRNA levels. Results obtained indicate that $M B$ fruit ethanol, ethyl acetate and hexane extracts have the ability to upregulate preproinsulin expression levels, enhance the increase in MafA and PDX-1 mRNA levels in RIN-m5F cells. These findings, which could most probably due to the occurrence of Cucurbitane-type triterpenoids in $M B$ fruit extracts (Kaushik et al., 2017), imply that indeed, upon its entry into the beta cells, glucose triggered the transcription and translation of the transcription factors MafA and PDX-1 which then resulted in the increase in mRNA levels of the pre-proinsulin gene ( $\mathrm{Fu}$ et al., 2013; Vanderford et al., 2007).

\section{Limitations and Strengths of the Study}

The main drawback in this study is that information that is more valued might have been acquired if this research was supplemented by studies of the effect of the $M B$ fruit extracts on the enzyme or/or protein activities of MafA, PDX-1, glucokinase and GLUT2 genes. Regardless of these constraints, numerous strengths associated to the present study can be outlined. Primarily, $M B$ extract of diverse polarities acquired over 
and done with the successive extraction of individual fruit material of this plant under research were examined in the current study. Furthermore, the current study investigated the concurrent effect of $M B$ fruit extracts on numerous factors that are part of the synthesis and secretory pathway of insulin. Thirdly, the effect of individual extract was explored at diverse concentrations in order to disclose the existence or the absence of a concentration-dependent outcome.

\section{Conclusion}

In this in vitro study, effect of crude $M B$ fruit extracts on selected aspects of the insulin synthesis and secretion by RIN-m5F $\beta$-cells were explored. The outcomes of this study showed that ethyl acetate, hexane and ethanol $M B$ fruit extracts have the capacity to enhance glucose uptake and to stimulate insulin synthesis and secretion by cultured RIN-m5F pancreatic beta cells. Furthermore, these same three $M B$ fruit extracts were able to upregulate gene expression levels of GLUT2, glucokinase enzyme, MafA and PDX-1 in cultured beta cells. It can be speculated and concluded on the basis of these results that $M B$ fruit extracts may in addition to their effects on inhibition of absorption of the intestinal glucose and sensitivity of insulin, exert their antidiabetic effect through stimulation of both the synthesis and secretion of insulin. Future research in our department will focus on the isolation, identification and characterization of the bioactive principles responsible for the different anti-diabetic mechanisms of this plant, Momordica balsamina crude fruit extracts.

\section{Acknowledgement}

The authors would like to acknowledge Dr OO Olaokun of the University of Pretoria for the contribution of RIN-m5F cells and Dr Mapula Razwinani of the Tshwane University of Technology for assisting with the Real-Time PCR instrument.

\section{Funding}

The Research Development Grant of the Sefako Makgatho Health Sciences University supported this work.

\section{Author Contribution}

Ananias Hodi Kgopa: Carried out the experimental work and writing of the manuscript.

Motetelo Alfred Mogale: Contributed in the design, supervision of the study, analysis of the data and editing of the manuscript.

Leshweni Jerry Shai: Contributed with the cosupervision of the study, modification of methodologies and analysis of results.
All authors have proofread and approved the final manuscript.

\section{Declaration of Conflict of Interest}

The authors declare no conflict of interest with respect to the research, authorship and publication of this article.

\section{References}

Ajabnoor, M. A. (1990). Effect of aloes on blood glucose levels in normal and alloxan diabetic mice. Journal of ethnopharmacology, 28(2), 215-220.

Bahuguna, A., Khan, I., Bajpai, V. K., \& Kang, S. C. (2017). MTT assay to evaluate the cytotoxic potential of a drug. Bangladesh Journal of Pharmacology, 12(2), Online-Apr.

Bhardwaj, N., Gauttam, V., \& Kalia, A. (2010). Evaluation of antidiabetic activity of Momordica balsamina Linn seeds in experimentally-induced diabetes. Journal of Chemical and Pharmaceutical Research, 2(5), 701-707.

Cerf, M. E. (2013). Beta cell dysfunction and insulin resistance. Frontiers in endocrinology, 4, 37.

Chaudhury, A., Duvoor, C., Reddy Dendi, V. S., Kraleti, S., Chada, A., Ravilla, R., ... \& Sasapu, A. (2017). Clinical review of antidiabetic drugs: implications for type 2 diabetes mellitus management. Frontiers in endocrinology, 8, 6 .

Davies, M. J., D’Alessio, D. A., Fradkin, J., Kernan, W. N., Mathieu, C., Mingrone, G., ... \& Buse, J. B. (2018). Management of hyperglycaemia in type 2 diabetes, 2018. A consensus report by the American Diabetes Association (ADA) and the European Association for the Study of Diabetes (EASD). Diabetologia, 61(12), 2461-2498.

Fu, Z., R Gilbert, E., \& Liu, D. (2013). Regulation of insulin synthesis and secretion and pancreatic Betacell dysfunction in diabetes. Current diabetes reviews, 9(1), 25-53.

Govindappa, M. (2015). A review on role of plant (s) extracts and its phytochemicals for the management of diabetes. J Diabetes Metab, 6(7), 1-38.

Joseph, B., \& Jini, D. (2013). Antidiabetic effects of Momordica charantia (bitter melon) and its medicinal potency. Asian Pacific Journal of Tropical Disease, 3(2), 93-102.

Karthikeyan, R., Somasundaram, S. T., Manivasagam, T., Balasubramanian, T., \& Anantharaman, P. (2010). Hepatoprotective activity of brown alga Padina boergesenii against $\mathrm{CCl} 4$ induced oxidative damage in Wistar rats. Asian Pacific Journal of Tropical Medicine, 3(9), 696-701. 
Kaushik, U., Aeri, V., Showkat, R. M., \& Ali, M. (2017). Cucurbitane-type triterpenoids from the blood glucose-lowering extracts of Coccinia indica and Momordica balsamina fruits. Pharmacognosy Magazine, 13(Suppl 1), S115.

Keller, A. C., Ma, J., Kavalier, A., He, K., Brillantes, A. M. B., \& Kennelly, E. J. (2011). Saponins from the traditional medicinal plant Momordica charantia stimulate insulin secretion in vitro. Phytomedicine, 19(1), 32-37.

Kgopa, A. H., Shai, L. J., \& Mogale, M. A. (2020). Effects of Sclerocarya birrea Stem-Bark Extracts on Glucose Uptake, Insulin Synthesis and Expression of Selected Genes Involved in the Synthesis and Secretion of Insulin in Rat Insulinoma Pancreatic Beta Cells. Asian Journal of Chemistry, 32(9), 2195-2202.

Komatsu, M., Takei, M., Ishii, H., \& Sato, Y. (2013). Glucose-stimulated insulin secretion: A newer perspective. Journal of diabetes investigation, 4(6), 511-516.

Mogale, M. A., Lebelo, S. L., Thovhogi, N., De Freitas, A. N., \& Shai, L. J. (2011). $\alpha$-Amylase and $\alpha$-glucosidase inhibitory effects of Sclerocarya birrea [(A. Rich.) Hochst.] subspecies caffra (Sond) Kokwaro (Anacardiaceae) stem-bark extracts. African Journal of Biotechnology, 10(66), 15033-15039.

Mukesh, R., \& Namita, P. (2013). Medicinal plants with antidiabetic potential-A review. American-Eurasian J Agric Environ Sci, 13(1), 81-94.

Nkansah, M. A., Shamsu-Deen, M., \& Opoku, F. (2018). Phytocompounds, Heavy Metal and Mineral Contents in honey Samples from Selected Markets in the Kumasi Metropolis. Emerging Science Journal, 2(5), 287-294.

Noor, A., Gunasekaran, S., \& Vijayalakshmi, M. A. (2017). Improvement of insulin secretion and pancreatic $\beta$-cell function in streptozotocin-induced diabetic rats treated with Aloe vera extract. Pharmacognosy research, 9(Suppl 1), S99.

Otimenyin, S. O., Uguru, M. O., \& Ogbonna, A. (2008). Antimicrobial and hypoglycemic effects of Momordica balsamina. Linn. J Nat Prod, 1, 3-9.

Prentki, M., \& Nolan, C. J. (2006). Islet $\beta$ cell failure in type 2 diabetes. The Journal of clinical investigation, 116(7), 1802-1812.

Ren, J., Jin, P., Wang, E., Liu, E., Harlan, D. M., Li, X., \& Stroncek, D. F. (2007). Pancreatic islet cell therapy for type I diabetes: understanding the effects of glucose stimulation on islets in order to produce better islets for transplantation. Journal of Translational Medicine, 5(1), 1-15.

Roffey, B. W., Atwal, A. S., Johns, T., \& Kubow, S. (2007). Water extracts from Momordica charantia increase glucose uptake and adiponectin secretion in 3T3-L1 adipose cells. Journal of Ethnopharmacology, 112(1), 77-84.
Saeedi, P., Petersohn, I., Salpea, P., Malanda, B., Karuranga, S., Unwin, N., ... \& Shaw, J. E. (2019). Global and regional diabetes prevalence estimates for 2019 and projections for 2030 and 2045: Results from the International Diabetes Federation Diabetes Atlas. Diabetes research and clinical practice, 157,107843

Sagbo, I. J., van de Venter, M., Koekemoer, T., \& Bradley, G. (2018). In vitro antidiabetic activity and mechanism of action of Brachylaena elliptica (Thunb.) DC. Evidence-Based Complementary and Alternative Medicine, 2018.

Salehi, B., Ata, A., V Anil Kumar, N., Sharopov, F., Ramírez-Alarcón, K., Ruiz-Ortega, A., ... \& Iriti, M. (2019). Antidiabetic potential of medicinal plants and their active components. Biomolecules, 9(10), 551.

Santa Cruz, X. M., \& Sfara, V. (2018). Chemical Signals are Involved in the Detection and Preference of Food Sources in Blattella Germanica. Emerging Science Journal, 2(5), 261-271.

Sowemimo, A., Okwuchuku, E., Samuel, F. M., Ayoola, O., \& Mutiat, I. (2015). Musanga cecropioides leaf extract exhibits anti-inflammatory and antinociceptive activities in animal models. Revista Brasileira de Farmacognosia, 25(5), 506-512.

Thakur, G. S., Bag, M., Sanodiya, B. S., Bhadauriya, P., Debnath, M., Prasad, G. B. K. S., \& Bisen, P. S. (2009). Momordica balsamina: a medicinal and neutraceutical plant for health care management. Current pharmaceutical biotechnology, 10(7), 667-682.

Thorens, B. (2015). GLUT2, glucose sensing and glucose homeostasis. Diabetologia, 58(2), 221-232.

Vanderford, N. L., Andrali, S. S., \& Özcan, S. (2007). Glucose induces MafA expression in pancreatic beta cell lines via the hexosamine biosynthetic pathway. Journal of Biological Chemistry, 282(3), 1577-1584.

Wajid, S., Menaka, M., Ahmed, F., \& Samreen, S. (2019). A literature review on oral hypoglycemic drugs - mechanistic aspects. Asian J. Pharm. Clin. Res, 12(11), 5-10.

Zandi, M., Masoumian, M., Shariatinia, A., \& Sanjabi, M. R. (2016). Optimal concentrations and synergistic effects of some herbal extracts on viability of dermal fibroblasts. Gene Cell Tissue, 3(4), 1-7.

Zhang, X., Han, W., Jiang, X., Li, M., Gao, L., \& Zhao, J. J. (2014). Chronic leucine exposure results in reduced but reversible glucose-stimulated insulin secretion in INS-1 cells. Molecular medicine reports, 9(6), 2554-2558. 